\title{
MENGENALI KEARIFAN LOKAL RUMAH VERNAKULAR MELALUI BENTUK DAN BAHAN BANGUNAN PADA RUMAH DI KUALA TRIPA, ACEH
}

\author{
Cut Nursaniah $^{\mathbf{1}}$ Izziah $^{2}$, Laila Qadri ${ }^{3}$ \\ Jurusan Arsitektur Fakultas Teknik Universitas Syiah Kuala \\ Jln. Teuku Nyak Arief Darussalam, Banda Aceh \\ *Email: ${ }^{1}$ cut.nursaniah13@gmail.com
}

\begin{abstract}
Infrastructure development, both buildings and roads, often result in changes in the surface condition of the landscape and lead to calamity. As happened in the residential area of the watershed Kuala Tripa, Aceh, lately kept flooded. The house is constructed on the ground ignores environmental character and threaten the sustainability of neighborhoods Kuala Tripa in the long term. Kuala Tripa form of physical environment is swamp, major rivers, and estuaries. Settlement of Kuala Tripa has a vernacular house that shows harmony and conformity with the environment. The occupancy adaptations can be identified by the shape and material of construction. Studies using qualitative descriptive methods to find local wisdom in the form and vernacular house building materials to be adapted and applied to the current construction. The results of the study on people's understanding of the architecture and building construction, the use of local building materials and the introduction of the local environment indicates that the potential of the vernacular architecture of Kuala Tripa can be used for residential development of the present and the future. Values in local wisdom and technology skills through shape and material the Kuala Tripa vernacular house building can be used as the basis for the development of the built environment today so adaptive to the environment and respond to disasters.
\end{abstract}

Keywords: local wisdom, vernacular house, form and buildings material.

\section{PENDAHULUAN}

Arsitektur vernakular merupakan arsitektur yang tumbuh dan berkembang dari arsitektur rakyat serta dibangun oleh tukang berdasarkan pengalaman (trial and error), menggunakan teknik dan material lokal serta merupakan respon adaptasi atas kondisi geografis lingkungannya. Bagaimana masyarakat lokal beradaptasi terhadap alam, akan memunculkan berbagai cara untuk menanggulanginya. Arsitektur vernakular mengalami perkembangan secara perlahan seiring perubahan kebiasaan masyarakatnya, antara lain pengaruh teknologi modern dan bahan bangunan modern. Suatu kondisi yang alami apabila suatu kebudayaan pasti akan mengalami perubahan kebudayaan setempat, namun perubahan yang diinginkan adalah perubahan yang akan tetap memelihara karakter inti dan akan menyesuaikan dengan kondisi pada saat ini, sehingga akan dapat terus dipertahankan. Menurut Papanek (1995), arsitektur vernakular merupakan pengembangan dari arsitektur rakyat yang memiliki nilai ekologis, arsitektonis dan alami karena mengacu pada kondisi alam budaya dan masyarakat lingkungannya. Sementara menurut Oliver (1997), dalam arsitektur vernakular terdapat saling pengaruh antara unsur alam/lingkungan dengan budaya masyarakatnya.

Rumah vernakular di Kuala Tripa adalah suatu bentuk kearifan lokal untuk menghadapi iklim dan menyesuaikannya dengan lingkungan sekitar, yang merefleksikan suatu masyarakat yang akrab dengan alamnya dengan memperhatikan potensi lokal, seperti potensi udara, tanaman, material alam, dan sebagainya hingga melahirkan suatu hunian yang menggunakan teknologi sederhana dan tepat guna. Kesederhanaan inilah yang merupakan keunikan sehingga tercipta bentuk khas dari rumah vernakular serta menunjukkan bagaimana 
menggunakan material secara wajar dan tidak berlebihan. Menurut Sartini (2004), Kearifan lokal merupakan gagasan-gagasan setempat (lokal) yang bersifat bijaksana, penuh kearifan, bernilai baik yang tertanam dan diikuti oleh anggota masyarakatnya.

Dalam aspek teknis, yang menjadi faktor vernakularitas pada unsur bentuk maupun materialnya adalah hal-hal yang berkaitan dengan keteknikan, seperti: cara membangun, teknik konstruksi yang digunakan, pemilihan material, dan hal-hal teknis lainnya yang memiliki nilai-fungsi dan mengandung makna berdasarkan adat masyarakat setempat. Teknologi rumah vernakular Kuala Tripa terbukti mampu mengantisipasi permasalahn gempa, banjir, dan iklim. Bahan bangunan dan konstruksi bangunan adalah dua unsur pembentuk bangunan.

Salah satu nilai yang dipelajari dari masa lalu, sebagai alternatif solusi yang dapat membentuk arsitektur masa sekarang dan berpengaruh pada masa depan adalah nilai kearifan lokal. Kearifan lokal rumah vernakular di kawasan Kuala Tripa ini dimaknai sebagai pola berfikir, gagasan, ide yang dinilai baik oleh masyarakat setempat terhadap kondisi lingkungan permukimannya berupa rawa dan rawan banjir. Kajian ini penting dilakukan untuk mendapatkan pengetahuan yang akan dikembangkan melalui kreatifitas dan inovasi sehingga dapat dimanfaatkan untuk kehidupan sekarang dan yang akan datang. Menurut Nursaniah (2015), konstruksi panggung merupakan solusi yang paling tepat untuk hunian pada kondisi lahan basah di kawasan DAS Kuala Tripa. Tidak ada kendala berarti dalam hal penerapan teknologi lokal yang sekarang dipraktekkan oleh tukang setempat jika diaplikasikan pada hunian bentuk panggung. Masyarakat bisa belajar memahami konsep adaptasi konstruksi rumoh santeut yang ada di kawasan tersebut yang merupakan kearifan lokal untuk mengatasi permasalahan setempat.

\section{METODE PENELITIAN}

Metode penelitian yang dipakai adalah metoda survei deskriptif (descriptive survey methods) karena data yang didapatkan berasal dari hasil observasi langsung di lapangan. Pengumpulan data dilakukan dengan teknik wawancara, observasi, dan penelusuran pustaka. Adapun penentuan sampel dilakukan dengan metode purposive sampling berdasarkan criteria yang telah ditetapkan, yaitu: rumah panggung yang masih dihuni.

Penelitian berlokasi pada permukiman di Daerah Aliran Air (DAS) Rawa Tripa, Kecamatan Tripa Makmur, Kabupaten Nagan Raya. Lokasi penelitian berjarak sekitar $287 \mathrm{~km}$ dari Kota Banda Aceh. DAS ini berada hampir sepanjang jalan Nagan Raya-Meulaboh, sekitar $25 \mathrm{~km}$ sebelum bermuara ke Kuala Tripa.
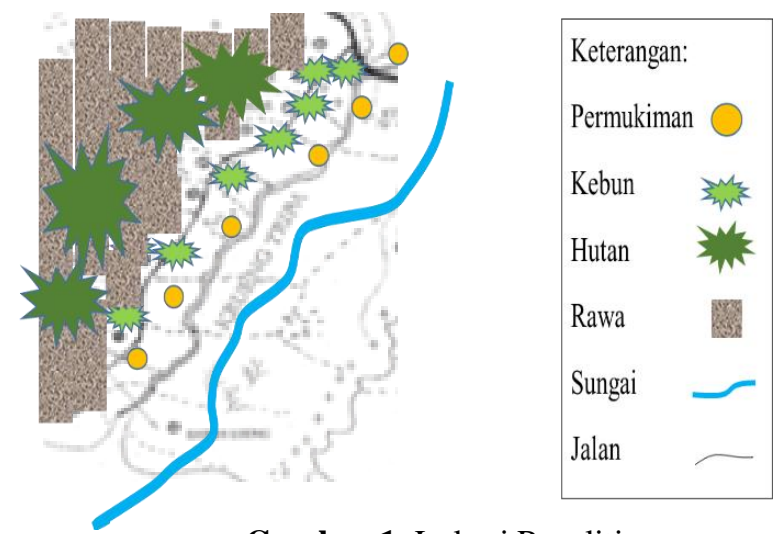

Gambar 1. Lokasi Penelitian

Perilaku sosial, arsitektur dan latar lingkungannya (kondisi ekologis, sosio, kultural yang spesifik dari lingkungan adalah faktorfaktor komunitas yang selalu berinteraksi. Jadi analisa dilakukan dengan melihat faktor-faktor yang mungkin mempengaruhi perwujudan bentuk rumah vernakular Kuala Tripa, antara lain: 1). Pendekatan environmental determinism menekankan bahwa bentuk dan pola rumah vernakular merupakan konsekuensi yang wajar atau respon pragmatis terhadap situasi iklim dan lingkungan tempat hunian tersebut berada. Arsitektur juga dipahami sebagai solusi relatif atau strategi adaptif (kolektif) terhadap ekologi; 2). Faktor religi atau kepercayaan juga dipandang sangat berpengaruh pada bentuk dan pola rumah.

\section{HASIL DAN PEMBAHASAN}

\section{Deskripsi Lingkungan}

Terdapat 11 (sebelas) wilayah sungai di seluruh Aceh yang mengalirkan air ke 481 anak sungai lainnya. Sungai Krueng Tripa yang melintasi lokasi penelitian termasuk salah satu sungai terbesar di Aceh. Di sepanjang sungai ini terdapat permukiman penduduk yang rentan mengalami banjir akibat meluapnya sungai tersebut. Kawasan Daerah Aliran Sungai (DAS) Rawa Tripa ini memiliki habitat dan ekosistem 
estuaria. Menurut Pickard (1967), Estuaria adalah perairan semi tertutup yang sebagian besar didominasi oleh substrat berlumpur yang merupakan endapan yang dibawa oleh air tawar dan air laut. Berdasarkan historis dan kondisi morfologinya kawasan Tripa Bawah ini memiliki karakter lahan yang relative landai sehingga terbentuk kawasan lahan basah berupa rawa. Ancaman banjir di permukiman Kuala Tripa terjadi akibat kondisi geografis kawasan yang berada di daerah dataran rendah dan lingkungan air/rawa. Banyaknya sungai dan alur air di sekitar permukiman turut meningkatkan ancaman banjir khususnya akibat pasang surut air laut.

Rumah vernakular yang masih ada di sepanjang DAS Rawa Tripa hingga saat ini sudah dihuni oleh empat generasi. Rumah bentuk panggung bermaterial kayu ini disebut rumoh santeut atau rumoh tampong limong. Rumah ini adalah varian lain dari Rumoh Atjeh yang merupakan rumah tradisional. Rumah vernakular ini terbukti mampu bertahan dari bencana gempa bumi dan banjir hingga tetap berdiri kokoh sampai sekarang. Hunian ini mampu bertahan hingga ratusan tahun tentunya didukung oleh konstruksi yang kokoh dan mutu bahan bangunan yang berkualitas.

\section{Kearifan Lokal Bentuk Bangunan}

Arsitektur vernakular merupakan pencerminan langsung dari budaya, nilai-nilai yang dianut, kebiasaan, dan keinginan masyarakat. Konsep bentuk dalam konteks budaya tradisional dipengaruhi oleh unsur alam sekitar serta hubungan dengan status sosial penghuninya. Pengaruh tersebut diaplikasikan melalui unsur-unsur bentuk hunian, bentuk denah, bentuk atap, sistem struktur dan bahan, bentuk ventilasi, dan tata ruang.

a. Bentuk hunian panggung

Bentuk hunian vernakular di Kuala Tripa dicirikan oleh bentuk rumah panggung kayu dengan ketinggian panggung 0,8-1 meter dari permukaan tanah.

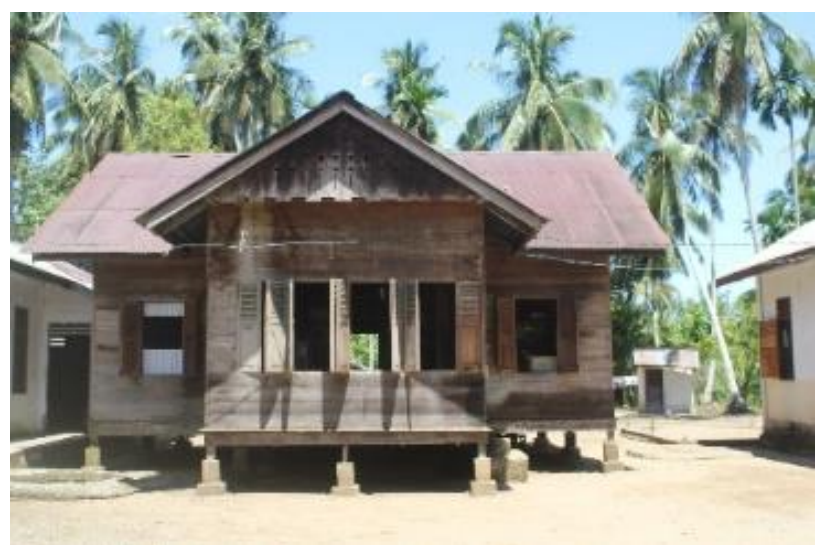

Gambar 2. Rumah Vernakular di Kuala Tripa

Bagian bawah rumah/kolong dibiarkan kosong. Peninggian lantai melalui konstruksi panggung dilakukan karena tanah berupa rawa yang mengalami air pasang dan surut di sepanjang tahunnya, dan banjir dari luapan sungai Krueng Tripa. Peninggian ini difungsikan untuk menghindari pasang surut air rawa, menghindari luapan banjir Sungai Krueng Tripa, dan untuk mengurangi tingkat kelembaban dengan menjauhkan lantai dari permukaan tanah. Bentuk konstruksi panggung tanpa menutup area kolong bangunan, memungkinkan masih tersedianya area resapan air di permukiman. Salah satu faktor yang menyebabkan terjadinya banjir berulang di Kuala Tripa adalah karena kurangnya daerah resapan air, akibat pembangunan hunian sekarang yang menutup permukaan tanah. Bentuk rumah panggung ini merupakan hasil adaptasi masyarakat terhadap lingkungan alam, seperti pasang surut air, dan menghindari banjir.

Bentuk panggung yang tidak tinggi ini juga merupakan solusi terhadap keberadaan lingkungan permukiman di daerah rawa dan daerah zona gempa kuat, seperti Aceh.

Rumah panggung merupakan solusi untuk meningkatkan penyegaran udara secara alamiah, karena angin juga dapat bergerak di bawah lantai sehingga seluruh permukaan rumah dikenai udara segar.

b. Bentuk denah

Hunian ini memiliki tata ruang yang sederhana, tegas, dan relatif seimbang, sesuai dengan prinsip bangunan tahan gempa. Rumah ini berkembang sejajar dengan perkembangan taraf kemajuan pikiran manusia mencari keselamatan dengan cara 
mengatasi atau menghindarkan diri dari gangguan dan bahaya.

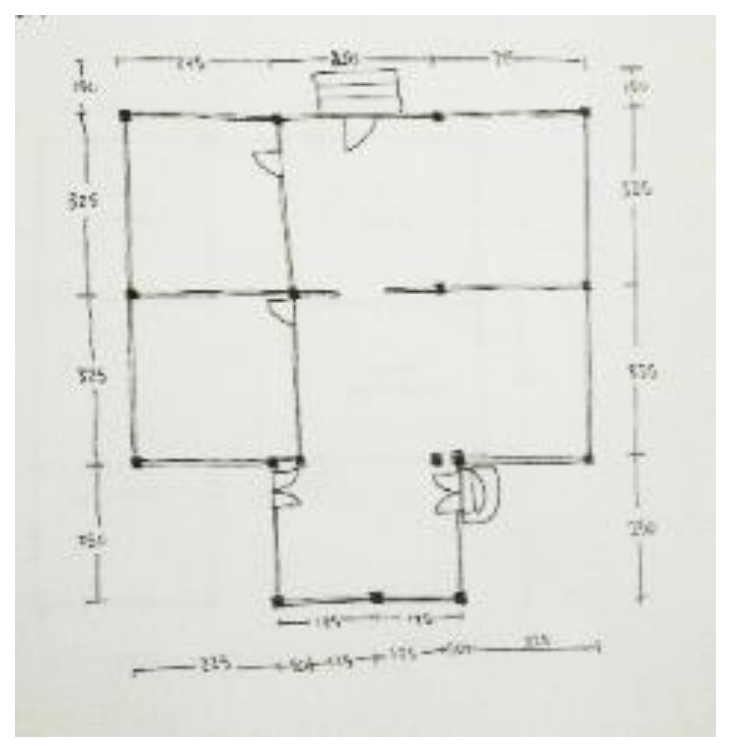

Adapun zona rumah berawal dari pekarangan (leun rumoh) yang seperti menjadi milik bersama (konsep ukhuwah Islamiah), setiap bangunan rumah biasanya terdiri dari ruang seuramo likeu (serambi depan), jure (ruang keluarga), seuramo likot (serambi belakang), dan dapue (dapur). Di bagian bawah rumah (lantai satu atau kadang disebut kolong rumah) dibiarkan kosong. Ruang utama atau rambat diisi dengan hamparan "tikar ngom lapis" tikar pandan. Kondisi ini memberikan keleluasaan ruang sehingga bisa multifungsi dan memberi sirkulasi udara yang baik. Secara kualitas ruang, ruang utama seperti ini juga mampu menghadirkan suasana kehangatan persaudaraan.

c. Sistem struktur

Dari segi konstruksi, penempatan tiang rumah menyebabkan pembagian ruang pada umumnya terdiri tiga ruang dan bertiang 16 . Konstruksi tiang kayu dan balok kayu dengan sistem lubang dan pasak seperti konstruksi tiang dan balok pada rumoh Atjeh, berperilaku jepit elastis berfungsi untuk merespon gempa. Sistem struktur yang fleksibel dari rumah vernakular Kuala Tripa ini sangat sesuai dengan prinsip rumah tahan gempa.

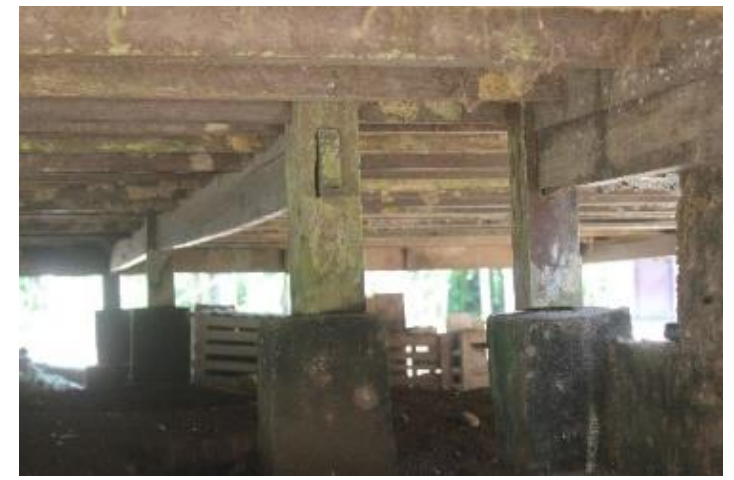

Gambar 4. Konstruksi Bawah

Rumah vernakular ini terbukti mampu bertahan dari gempa karena struktur utama yang kokoh dan elastis, sama seperti konstruksi pada Rumoh Atjeh (rumah tradisional Aceh). Struktur utama konstruksi bangunan elastis karena antara tiang dan lantai diikat dengan pasak (bajoe) tanpa menggunakan paku, serta membentuk rigid (kotak tiga dimensional yang utuh). Karena elastis dan saling mengunci, struktur hunian ini kokoh dan tahan getaran dan goyangan. Karena hubungan antara struktur utama dengan lainnya saling mengunci, sehingga bila terjadi goyangan seperti gempa, struktur ini bisa mengikuti arah gerakan tersebut sehingga tidak terjadi kerusakan. Tiga komponen struktur yang menjadikan hunian kokoh terhadap getaran dan goyangan, yaitu 1). Pondasi sebagai pusat beban bangunan yang besar; 2). Tiang dan balok sebagai tumpuan semua konstruksi, sebagai penyalur beban dari atas dan dari samping; serta 3). rangka atap yang menjadi penyangga dari atas.

d. Bentuk ventilasi

Terkait dengan iklim tropis, penghawaan ruang dalam sangat baik karena udara dapat mengalir dengan baik melalui tingkap krepyak (jendela), sela-sela antara lantai yang terbuat dari papan kayu, maupun selasela antara atap dan dinding, dan ornamen pada atap yang bisa mengalirkan udara. Selain itu, sela-sela antara lantai juga mempermudah pembuangan kotoran di dalam ruang. 


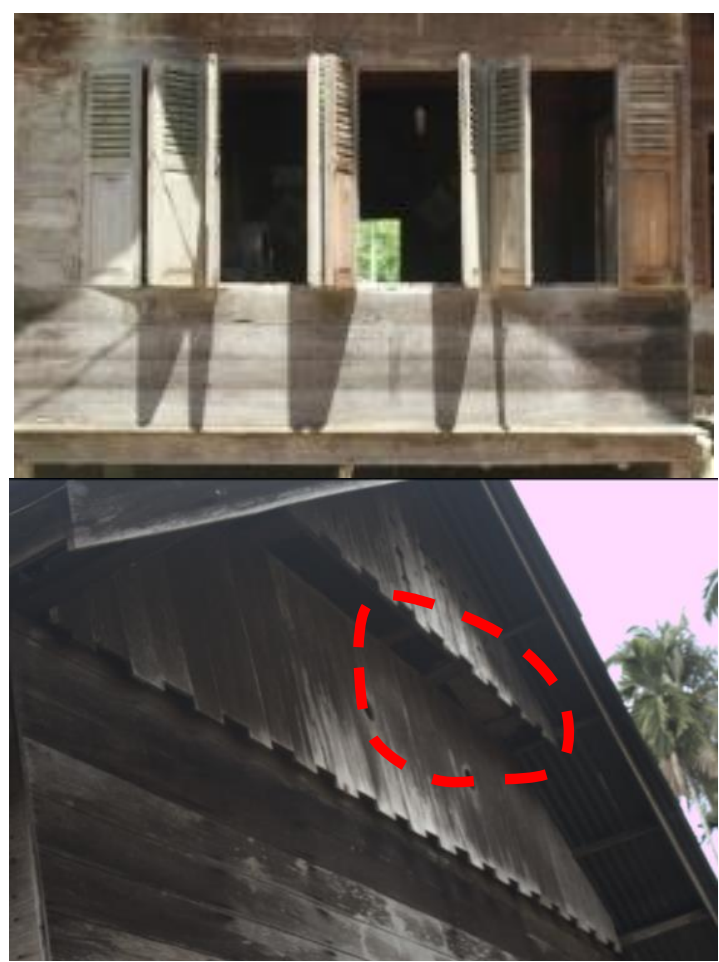

Gambar 3. Bukaan dan Ventilasi

e. Bentuk atap

Bentuk atap segitiga yang bervolume besar berfungsi untuk melindungi rumah dari panas, hujan, petir, angin, dan sebagainya. Atap rumah vernakular ini juga berfungsi proteksi untuk menahan panas yang berlebihan, mencegah tampias hujan, dan mengurangi pergerakan angin. Kemiringan atap 35 derajat digunakan untuk mempercepat limpahan air hujan. Teritisan lebar terdapat di sekeliling bangunan untuk menaungi hunian dari tampias hujan maupun sinar matahari langsung.

\section{Bahan Bangunan}

Secara keseluruhan material yang digunakan untuk konstruksi rumah vernakular di Kuala Tripa adalah material yang adaptif terhadap iklim dan lingkungan setempat. Material utama yang digunakan sepenuhnya adalah kayu, mengingat ketersediaannya yang melimpah di hutan-hutan Pesisir Barat Aceh. Kecuali pada pondasi menggunakan material beton dan pada atap menggunakan material seng.

Kayu yang digunakan untuk tiang dan balok adalah jenis kayu keras. Tiang atau tameh terbuat dari material kayu pilihan yang berasal dari bak mane (pohon laban), kayu merbau, ataupun kayu enau (temor) yang sangat kokoh dan pohon-pohon yang di dapat dari sumber daya alam Aceh berupa material yang tahan rayap. Bobot material dari tiang dan balok sangat ringan serta dapat meneruskan getaran dan tidak memberikan beban getaran yang berlebih pada tiang sehingga tidak menyebabkan patahan atau retakan.

Material kayu yang digunakan untuk tiang dan balok lantai sangat adaptif dengan kondisi luar ruangan terutama ketahanannya terhadap panas dan hujan.

Untuk lantai pada ruang dalam juga menggunakan kayu yang berupa bilah-bilah papan yang disusun rapat. Dinding dari papan kayu disusun vertikal untuk mempercepat limpahan air hujan yang tampias. Celah-celah antar sambungan digunakan untuk memasukkan angin sekaligus pencahayaan selain melalui bukaan.

Atap berbentuk pelana menggunakan material kayu untuk rangka atap dan seng sebagai material penutup atap. Dahulu material penutup atap adalah anyaman daun rumbia. Namun semenjak material seng ada di pasaran, masyarakat sudah menggunakan material ini ringan, lebih aman terhadap angin kencang yang kerap melanda wilayah pesisir Barat, dan juga lebih aman terhadap kebakaran.

Konstruksi rumah panggung harus ringan, sebaiknya menggunakan konstruksi kayu dengan pondasi umpak. Selain lebih ringan dari konstruksi beton juga sudah teruji kekuatannya. Sambungan di tiap pertemuan kayu biasanya juga menggunakan kayu. Sambungan kayu bersifat lentur sehingga memungkinkan bangunan bergerak mengikuti arah gempa. Hal ini akan membuat konstruksi terhindar dari patahan struktur.

\section{Fungsi Elemen Pembentuk Bangunan}

Elemen panggung digunakan untuk mengatasi kelembaban, gangguan air pasang, banjir, dan melewatkan angin. Beranda digunakan sebagai area transisi agar tidak mengalami tampias dan silau jika bagian muka bangunan diberikan bukaan. Bukaan pintu dan jendela, lebih difungsikan sebagai penghawaan dibandingkan untuk memasukkan pencahayaan. Teritisan yang digunakan, hanya berfungsi pada bagian depan dan belakang. Pada bagian samping bangunan, teritisan tidak cukup 
memberikan perlindungan terhadap tampias air hujan, dan silau matahari. Atap bervolume besar dan berventilasi untuk menghapus panas turun ke ruang di dalam hunian, didukung oleh adanya plafon pada bagian. Penutup atap seng, menghindarkan air hujan meresap masuk ke dalam ruangan. Sedangkan konstruksi material kayu yang elastis dan ringan berfungsi untuk mengendalikan getaran dan goyangan akibat gempa bumi.

Fungsi elemen-elemen pembentuk bangunan pada rumah vernakular di Kuala Tripa, yaitu sebagai pengendali iklim, bencana banjir dan gempa bumi. Namun material elemen pembentuk bangunan bisa saja disesuaikan dengan teknologi sekarang, mengingat penggunaan kayu di Aceh sudah terbatas. Di samping itu masyarakat setempat juga menguasai teknik konstruksi lokal dengan cara cor beton, karena di daerah tersebut tidak tersedia bata. Sebenarnya rumah panggung bisa dibuat dari bahan apa saja selain kayu, misal bambu dan beton.

Fungsi elemen-elemen pembentuk rumah vernakular di Kuala Tripa berikut aplikasi menggunakan bahan bangunan alternatif (Tabel 1).

Tabel 1. Fungsi Elemen-elemen Pembentuk Hunian dan Material Alternatif

\begin{tabular}{|c|c|c|c|}
\hline No. & Elemen & Fungsi & Material \\
\hline 1. & $\begin{array}{l}\text { Panggung } \\
\text { (kayu) }\end{array}$ & $\begin{array}{l}\text { Respon pada } \\
\text { iklim, banjir, } \\
\text { dan gempa }\end{array}$ & $\begin{array}{l}\text { Kayu, } \\
\text { beton }\end{array}$ \\
\hline 2. & $\begin{array}{l}\text { Pondasi } \\
\text { (beton) }\end{array}$ & $\begin{array}{l}\text { Respon pada } \\
\text { banjir, gempa }\end{array}$ & Beton \\
\hline 3. & $\begin{array}{l}\text { Tiang dan } \\
\text { balok }\end{array}$ & Banjir, gempa & $\begin{array}{l}\text { Kayu, } \\
\text { beton }\end{array}$ \\
\hline 4. & $\begin{array}{l}\text { Dinding } \\
\text { papan }\end{array}$ & $\begin{array}{l}\text { Respon pada } \\
\text { iklim, gempa }\end{array}$ & $\begin{array}{l}\text { Kayu, } \\
\text { beton }\end{array}$ \\
\hline 5. & $\begin{array}{l}\text { Atap } \\
\text { (seng) }\end{array}$ & $\begin{array}{l}\text { Respon pada } \\
\text { iklim, gempa, } \\
\text { kebakaran }\end{array}$ & $\begin{array}{l}\text { Seng, } \\
\text { genteng }\end{array}$ \\
\hline 6. & Teritisan & $\begin{array}{l}\text { Respon pada } \\
\text { iklim (hujan, } \\
\text { silau) }\end{array}$ & $\begin{array}{l}\text { Respon } \\
\text { pada } \\
\text { cahaya } \\
\text { silau bisa } \\
\text { diganti } \\
\text { dengan } \\
\text { vegetasi }\end{array}$ \\
\hline 7. & $\begin{array}{l}\text { Bukaan } \\
\text { (jendela } \\
\text { dan pintu } \\
\text { sebagai } \\
\text { ventilasi) }\end{array}$ & $\begin{array}{l}\text { Respon pada } \\
\text { iklim }\end{array}$ & kayu \\
\hline
\end{tabular}

\section{KESIMPULAN}

Pada dasanya bentukan hunian di Kuala Tripa merupakan hasil respon penghuni terhadap kondisi geografis. Rumah berbentuk panggung memberikan kenyamanan thermal (penyesuaian suhu di dalam rumah dengan cepat karena aliran udara bagus), keamanan terhadap bencana banjir (ketinggian panggung di atas elevasi banjir, kolong rumah menjadi area resapan air yang optimal) dan gempa bumi (konstruksinya elastis) kepada penghuninya.

Rumah vernakular panggung ini juga membuat pandangan tidak terhalang dan memudahkan sesama warga saling menjaga rumah serta ketertiban kampung. Jadi rumah panggung dapat dimanfaatkan sebagai sistem kontrol yang praktis untuk menjamin keamanan, ketertiban dan keselamatan penghuni dari banjir, gempa, binatang buas, dan orang asing. Zona privat dan publik terpisah secara tegas, dimana masyarakat memfungsikan zona publik pada bagian halaman rumah, sedangkan zona privat di bagian panggung.

Keselarasan nilai-nilai kearifan lokal rumah vernakular di Kuala Tripa, Aceh yang merespon kondisi geografis setempat perlu dilestarikan karena memiliki banyak kelebihan. Hingga sekarang rumah vernakular ini masih sangat adaptif untuk merespon banjir dan gempa. Kelemahan, yaitu dianggap tidak efisien lagi bukan pula suatu penghalang bagi warga untuk tetap bertempat tinggal di hunian bentuk panggung karena hunian vernakular tersebut adalah pilihan terbaik untuk kawasan Kuala Tripa yang menjadi langganan banjir.

Namun bentuk bangunan juga ditentukan oleh fungsinya, menurut kebutuhan dasar penghuninya dan cara membangunnya, yaitu cara membatasi ruang tersebut secara konstruktif dengan lantai, dinding, susunan atap, dan sebagainya.

\section{Daftar Pustaka}

Kingston WM. Heath, (2009) Vernacular Architecture and Regional Design: Culture Process and Environmental Response.

Nursaniah, Cut, Izziah, Laila Qadri, 2015, The Typology of Stilted House Construction in Wetland in the West Coast Aceh (Case Study: The Watershed (DAS) Rawa Tripa region, Nagan Raya). Proceeding: The $5^{\text {th }}$ 
Annual International Conference Syiah Kuala University (AIC-Unsyiah). ISSN: 2089-208X.

Papanek, Victor (1995) the Green Imperative, Ecology and Ethics in Design and Architecture, Thames and Hudson.

Pickard G. L. (1967) Descriptive Physican Oceanography. Second Edition. Massachussets: Jones and Bartelett Publisher.

Oliver, Paul (ed), (1997) Encyclopedia of Vernacular Architecture of the World. 3 Vois. Cambridge: Cambridge University Press.

Sartini, (2004) Menggali Kearifan Lokal Nusantara sebuah Kajian Filsafat Dalam: Jurnal Filsafat. (Internet). (Dikutip 23 Desember 2016); diunduh dari: http://www.searchdocument.com/pdf/1/1/ MenggaliKearifan-Lokal-Nusantara-SebuahKajian-Filsafat.html. 